\title{
Corrosion of reinforcing steel in reinforced and prestressed concrete bridges
}

\author{
A.-K. M. Hussain \& A. M. Rifai \\ Civil Engineering Department, Engineering College, \\ Al-Marghab University, Libya
}

\begin{abstract}
The corrosion of reinforcing steel has led to the premature deterioration of many concrete bridges in countries throughout the World, such as Libya, before their design life is attained. This has placed tremendous financial burden on such countries and local transportation organizations in their attempts to halt ongoing reinforcing steel corrosion in the existing structures that are still functional and to replace those structures that have already deteriorated to the point that it does not make any economic sense to keep on maintaining them. In addition, badly deteriorated bridges have considerable adverse effects on the nation's economic output and also place the safety of motorists at risk. In this study the effects of several factors on the corrosion behavior of steel have been studied. These factors are chloride ion concentrations and environmental variables such as temperature and relative humidity. The interactions of chloride ion concentration, temperature, and relative humidity on the corrosion behavior of steel are complex. In addition, the effect of the concrete mix components, such as water/cement ratio and proper selection of cement type, mineral admixture, and fine aggregate, coarse aggregate, and air content on the corrosion rate of reinforcing steel are studied.
\end{abstract}

Keywords: reinforcing steel corrosion, reinforced concrete bridges, corrosive environment, corrosion of reinforcing steel, corrosion of steel reinforcement in concrete.

\section{Introduction}

Reinforcing steel bars are placed in regions of low tension in concrete bridges.

Concrete has a tendency to crack eventually if proper curing is not observed. The resistance of mild steel bars to corrosion can not be significantly improved 
by just modifying its composition, grade, or the level of stress. Therefore, to prevent corrosion of steel reinforcement in concrete located in corrosive environment either the conventional mild steel reinforcement must be coated with an effective and economical barrier to prevent contact with chloride, moisture, and oxygen, or reinforcement made of corrosion-resistant materials must be used as mentioned by Glasser and Sagoe-Crentsil [1], Hime [2], Baboian [3], Virmani and Clemena [4] and Thompson and Lamkard [5]. Among the above two options, application of a suitable coating on the mild steel reinforcement may be the most economical. The coated reinforcing steel bars must be resistant to damage during transport from a plant to a construction site, storage at construction site, and placement in the structure. It must also be durable in severe service environment and capable of maintaining its structural function throughout the service life of the structure, and be economical.

\section{Corrosion control in new concrete constructions}

Corrosion control of reinforcing steel bars in new concrete constructions, such as bridges, buildings exposed to the marine environments, and wastewater treatment tanks, require the use of a combination of different measures, such as: adequate depth of concrete cover, quality of concrete, corrosion inhibitors admixture and corrosion-resistant reinforcement. At least $50 \mathrm{~mm}$ of concrete cover reduces the ability of corrosive agents to penetrate the concrete and corrode the reinforcing steel bars. The most common cause of corrosion staining on concrete decks is poor placement of the reinforcing steel bars.

\section{Quality of concrete}

The quality of concrete is of utmost importance in determining the durability of reinforced concrete bridge members exposed to chlorides and subjected to intermittent wetting. Concrete contains a network of capillary channels that allows water and oxygen, both important to steel bars corrosion, to permeate into the concrete. Corrosion occurs because a salt solution, or water and carbon dioxide, penetrate the concrete. Lowering the porosity and the permeability of the concrete reduces the chances of contamination. At a low (W/C) ratio of 0.5 and good consolidation lead to low porosity in the concrete, which can lead to reduced permeability (hydraulic conductivity) coefficient of the concrete. Reduced permeability leads to reduction in the amount of chloride ions carried by water into the concrete. At a $(\mathrm{W} / \mathrm{C})$ ratio of 0.5 , carbonation will penetrate $10 \mathrm{~mm}$ in ten years. A low $(\mathrm{W} / \mathrm{C})$ ratio also offers higher strength to the concrete, which would extend the time before stresses resulting from steel corrosion cause the concrete to crack. If the strength is low $(20.7 \mathrm{MPa})$ carbonation can reach $25 \mathrm{~mm}$ in seven years. Strong concrete with a low (W/C) ratio will have a low permeability and be less susceptible to corrosion as mentioned by Gu et al [6]. The occurrence of corrosion of steel bars in concrete bridges can be avoided by investigation into how concrete material and mix variables affect the corrosion behavior of steel bars. The environmental factors of 
chloride concentration, temperature and humidity significantly affect the corrosion behavior of steel bars in concrete. A localized corrosion was noted at a location where the reinforcement had been exposed previously. In concrete with $0.50(\mathrm{~W} / \mathrm{C})$ ratio, when galvanized bars are used, the corrosion rate was about $30 \%$ and the corresponding metal loss was $22 \%$, in comparison to black steel. And, in the same concrete, when galvanized steel bars were used only in the top mat, the corrosion rate was twice of that observed when only black steel bars were used in both mats. Essentially, these results suggested that the use of galvanized steel bars would not provide extra benefit over black steel bars, if (W/C) ratio in the concrete is kept low as mentioned by McDonald et al $[7,8]$, Baboian [9], Thompson et al [10], Clear [11], Smith and Virmani [12], McDonald et al [13], Dagher and Kulendran [14] and Hussain et al [15].

\section{Adequate concrete cover and chloride content}

Chloride ion is the main corrosive agent. When chlorides penetrate concrete from external sources, such as de-icing salts and seawater, carbon steel bars corrode and rust forms; occupying a volume about three to seven times that of the original steel resulting in the surrounding concrete cracking as mentioned by Pettersson [16] and Virmani [17]. If a concrete structure is to be durable in a corrosive environment, it is necessary to provide an adequate depth of concrete cover over the first layer of reinforcing steel bars so that it would not be easy for chloride ions to reach the steel bars.

\section{Case study - the model of the transient diffusion of chloride through a porous concrete}

The adequate depth of concrete cover over the first layer of reinforcing steel bars can be determined by application of Fick's Second Law of diffusion, which adequately models the transient diffusion of chloride through a porous material, such as concrete. A closed - form solution of Fick's Second Law (a secondorder differential equation) can be expressed as

$$
\mathrm{C}_{(\mathrm{x}, \mathrm{t})}=\operatorname{Co}\{1-\operatorname{erf}(\mathrm{y})\}
$$

where

$$
y=\frac{x}{2 \cdot \sqrt{D_{c} \cdot t}}
$$

and

$\mathrm{C}_{(\mathrm{x}, \mathrm{t})}=$ Measured chloride concentration at the desired depth $\mathrm{x}$, for purposes of service life estimates, assumed to equal the chloride threshold, i.e. the chloride content that will initiate corrosion, (p.p.m.). 
$D_{c}=$ Chloride molecular diffusion coefficient $\left(\mathrm{mm}^{2} /\right.$ year). It is a function of the concrete permeability, environmental factors, and the presence of cracks.

$\mathrm{x}=$ Depth of reinforcing steel bars (mm).

$\mathrm{C}_{0}=$ Constant mean surface chloride concentration measured at $12 \mathrm{~mm}$ below the deck surface (p.p.m.).

$\mathrm{t}=$ Time to reach the corrosive chloride threshold, i.e. the time for the chloride to reach the depth of reinforcing steel bars, (year).

Eqn (1) can be rewritten as

$$
\operatorname{erf}(\mathrm{y})=1-\left\{\mathrm{C}_{(\mathrm{x}, \mathrm{t})} / \mathrm{Co}\right\}
$$

Also, Eq. (2) may be rewritten as

$$
t=\frac{x^{2}}{\left(4 y^{2} \cdot \mathbf{D}_{c}\right)}
$$

Eqn (3) is applicable to concrete structures where the chloride ions enter from one direction, such as concrete bridge decks and piers. Using relationships (3) and (4), the time t required to reach the corrosive chloride threshold may be computed for a certain concrete cover, $\mathrm{x}$ and a known chloride concentration $\mathrm{C}_{(\mathrm{x}, \mathrm{t})}$ which corresponds to the onset of steel reinforcement corrosion. Repeating this process for different values of $x$ and plotting the time $t$ versus the concrete cover $\mathrm{x}$ shows the general trend of the relationship between the two variables. From such a plot, one can determine the minimum concrete cover required to prevent the onset of steel corrosion before the desired service life of the structure is reached.

For a known chloride concentration $\mathrm{C}_{(\mathrm{x}, \mathrm{t})}$, the value of erf $(\mathrm{y})$ may be calculated using Eq. (3). The corresponding value of y may be interpolated from the table "Error function values y for the argument of y" given in Appendix A of Hussain [18] or from other suitable references. Eq. (4) is used to calculate the time of threshold of chlorides corresponding to a certain concrete cover $\mathrm{x}$.

In this work it has been found that the chloride molecular diffusion coefficient $\mathrm{D}_{\mathrm{c}}$ (the rate at which chloride permeates through concrete) is 32.26 $\left(\mathrm{mm}^{2} /\right.$ year), the constant mean surface chloride concentration in the bridges $\mathrm{C}_{0}$ was 8300 (p.p.m.) and the typical chloride threshold for uncoated steel bars is 700 (p.p.m.).

Using these data items, and starting with $\mathrm{x}=50 \mathrm{~mm}$, Eq. (3) may be used to find the value of $\operatorname{erf}(\mathrm{y})$ as:

$$
\operatorname{Erf}(y)=1-\frac{700}{8300}=0.9157
$$


Next, from the table mentioned above the corresponding value of $\mathrm{y}$ is interpolated to be 1.2228. Using Eq. (4) the time $t$ is calculated as:

$$
t=\frac{50^{2}}{4(1.2228)^{2} \cdot(3226)}=13
$$

Repeating this process for values of $\mathrm{x}$ of $55 \mathrm{~mm}, 60 \mathrm{~mm}, 65 \mathrm{~mm}, 70 \mathrm{~mm}, 75$ $\mathrm{mm}$ and $80 \mathrm{~mm}$ and plotting the results as in Figure 1, we notice the relationship is almost linear. If we assume that the service life of the structure is about 25 years, we may conclude from the Figure that the minimum concrete cover should be about $68 \mathrm{~mm}$. Note that Figure 1 applies to uncoated steel bars only. Once Figure 1 has been constructed, it serves as a quick way to estimate the required concrete cover for a certain service life of the structure.

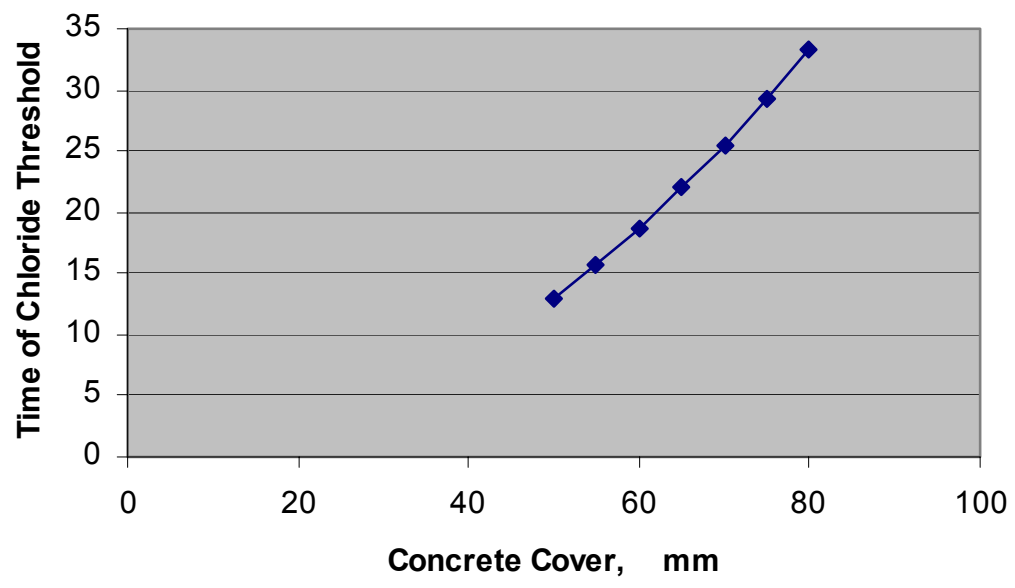

Figure 1: Relationship between concrete cover and time of corrosive chloride threshold.

However, even with adequate concrete cover, corrosion of reinforcement can still occur because, invariably, concrete will crack. In addition, presence of variances in the concrete cover and in the density of the placed concrete across a structure will eventually create corrosion micro-cells (consisting of cathodes and anodes), which drive steel corrosion. Therefore, other supplementary protective measures also need to be adopted in a new construction. Figure 2 provides a photograph of this damage. This explains why the problem of reinforcing steel bars corrosion is considerably more severe in the marine environment of Libya's northern cities, such as Al-Khoms, Tripoli and Musrata (because of high humidity) than in the other cities situated in the south. Figure 3 shows a photograph of corrosion-induced concrete spalling on a bridge piling. 


\section{Results}

The following are the most important findings resulting from this study:

1. Chloride concentrations higher than 700 p.p.m can produce a wide range of corrosion behavior of reinforcing steel bars in concrete.

2. The interactions of chloride ion concentration and environmental variables, such as, temperature and relative humidity on the corrosion behavior of reinforcing steel bars are complex.

3. The corrosion rate of reinforcing steel bars can vary significantly based on the concrete mix components. The most significant beneficial effects were obtained from use of low $(\mathrm{W} / \mathrm{C})$ ratio and proper selection of cement type, mineral admixture and fine aggregate.

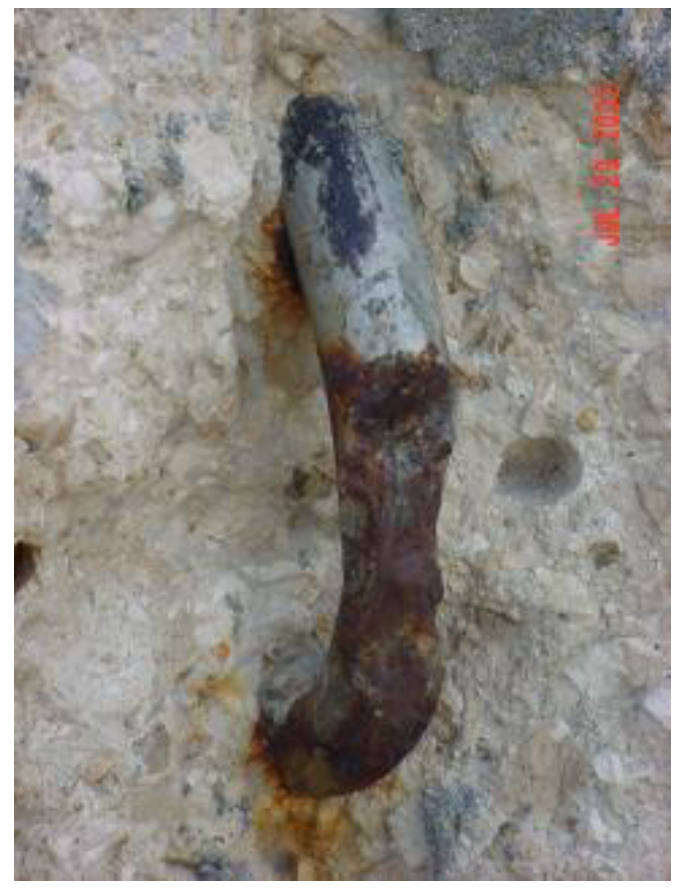

Figure 2: $\quad$ Corrosion of an exposed reinforcing bar.

4. Bridge utilizing epoxy powder-coated reinforcing steel bars revealed some problems, such as damage to the coating during transport and handling and the cracking of coating (in the bend areas) arising from the bending of bars at construction sites. To eliminate these problems, measures such as bending the steel bars before coating, increasing bar supports during shipping (to prevent abrasion between bars) and using padded bundling bands and nylon slings during loading and unloading were adopted.

5. A small exposed area of reinforcing steel bars would be susceptible to intense corrosion and require patching or repair of the coating damages. 
This led to a decrease in the cost of epoxy-coated reinforcing steel bars and their wider use in bridges by many countries.

6. Some aspects, such as bar size, deformation pattern, grade of steel, and slab design used has effects on the occurrence of corrosion.

7. In general, the corroded reinforcing steel bars are placed in locations in the structures where concrete cover was relatively shallow, the chloride contents were high and there were cracks in the concrete.

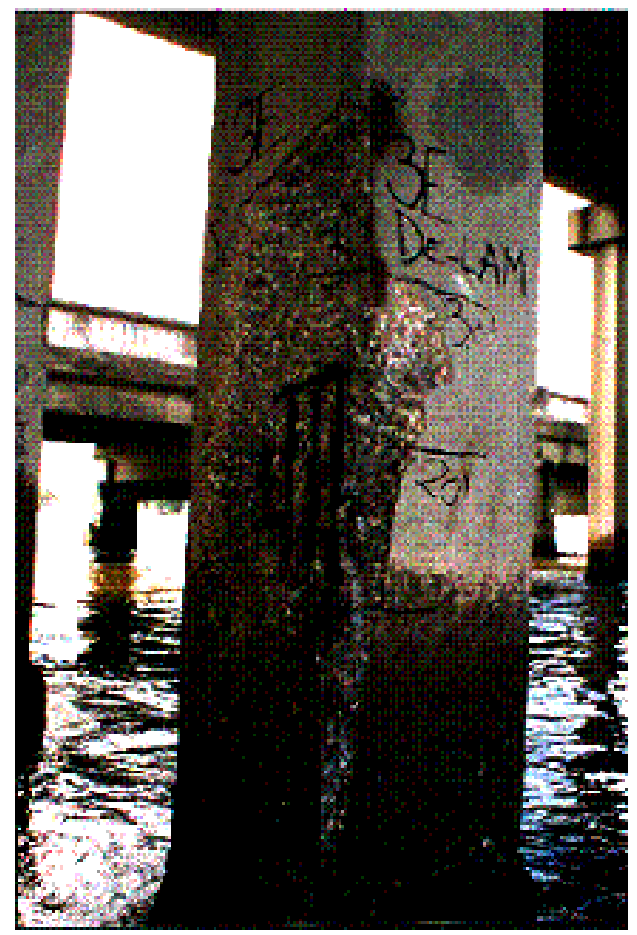

Figure 3: $\quad$ Photograph of a cracked and spalled marine bridge piling.

\section{Conclusions}

The following conclusions can be made on the performance of reinforcing steel bars in the bridge decks:

1. Some cases of corrosion in bridge decks were centered at a construction joint.

2. Most cases of corrosion reinforcing steel bars were attributed to superficial corrosion that was already present on the reinforcing steel bars at the time of construction.

3. The use of quality concrete and adequate cover, proper finishing and curing of concrete, and proper manufacturing and handling of epoxy- 
coated reinforcing steel bars are important in ensuring effective corrosion protection in concrete bridge decks.

4. Cracks in the concrete allow moisture and chloride an easy and direct access to the reinforcing steel bars as opposed to the normally slow diffusion process through sound concrete. The cracks probably allow the bars to remain wet longer than normal and they corrode.

5. Application of a suitable, stable organic coating, including epoxies (in both liquid and powder forms), on the reinforcing steel bars is the more economical solution to serve as a barrier for isolating the reinforcing steel bars from moisture, chloride ions, and oxygen, thereby preventing corrosion and keep many concrete bridges away from the premature deterioration.

6. To control the major causes of corrosion of reinforcing steel bars in concrete, the concrete must block the ability of salt to make contact with the steel bars and retard the progression of carbonation. To do this, the following ten ways should be considered: (1) -Reduce the permeability of the concrete. (2) - Ensure at least $50 \mathrm{~mm}$ of concrete cover the reinforcing steel bars. (3) - Coat the reinforcing steel bars with epoxy. (4) - Use a corrosion inhibitor in the concrete. (5) -Use cathodic protection. (6) - Keep the concrete dry. (7) - Use a blended cement in the concrete. (8) - Use a water-reducing agent; low-, mid-, or high-range. (9) - Cure the concrete properly. (10) - Use other special treatments.

\section{References}

[1] F. G. Glasser and K. K. Sagoe-Crentsil, "Steel in Concrete: Part II Electron Microscopy Analysis", Magazine of Concrete Research, Vol. 41, No. 149, 1989, pp. 213-220.

[2] W. G. Hime, "The Corrosion of Steel-Random thoughts and Wishful Thinking”. Concrete International, Vol.15, No.10, 1993, pp. 54-57.

[3] R. Baboian, "Environmental Aspect of Automotive Corrosion Control", Materials Performance, Vol.32, No.5, 1993, pp. 46-49.

[4] Y. Paul Virmani and Gerardo G. Clemena, 1998, Corrosion ProtectionConcrete Bridges, Report No.FHWA-RD-98-088, Turner-Fairbank Highway Research Center, 6300 Georgetown Pike, McLean, Virginia 22102 - 2296, Office of Engineering Research and Development Federal Highway Administration, 6300 Georgetown Pike McLean, Virginia 22102 $-2296$.

[5] N. G. Thompson and D. R. Lankard, "Improved Concrete for Corrosion Resistance". Report No. FHWA-RD-96-207, Federal Highway Administration, Washington, D. C., 1995.

[6] P. Gu, Y. Fu, P. Xie, and J. J. Beaudoin, "Effect of Uneven Porosity in Cement Paste and Mortar on Reinforcing Steel Corrosion”, Cement and Concrete Research, Vol. 24, No. 6, pp.1055-1064, 1994. 
[7] D. B. McDonald, D. W. Pfeifer, and G. T. Blake, The Corrosion Performance of Inorganic-, Ceramic- and Metallic-Clad Reinforcing Bars and Solid Metallic Reinforcing Bars in Accelerated Screening Tests. Report No. FHWA-RD-96-085, Federal Highway Admin., Washington, D.C., 1996 .

[8] D. B. McDonald, M. R. Sherman, D. W. Pfeifer, and Y. P. Virmani, "Stainless Steel Reinforcing as Corrosion Protection", Concrete International, Vol. 17, No. 5, pp. 65-70, 1995.

[9] R. Baboian, "Synergistic Effects of Acid Deposition and Road Salts on Corrosion", in Corrosion Forms and Control for Infrastmcture, STP 1137, V. Chaker, ed., Amer. Soc. for Test. and Materials, Philadelphia, Pa., 1992.

[10] N. G. Thompson, K. M. Lawson, D. R. Lankard, and Y. P. Virmani, "Effect of Concrete Mix Components on Corrosion of Steel in Concrete", presented at Corrosion/96, Denver, Colorado, 1996.

[11] K. C. Clear, "Effectiveness of Epoxy-Coated Reinforcing Steel", Final Report submitted to Canadian Strategic Highway Research Program, Toronto, Canada, 1992.

[12] J. L. Smith and Y. P. Virmani. "Performance of Epoxy Coated Rebars in Bridge Decks". Report No. FHWA-RD-96-092, Federal Highway Administration, Washington, D. C., 1996.

[13] D. B. McDonald, M. R. Sherman, and D. W. Pfeifer, "The Performance of Bendable and Nonbendable Organic Coatings for Reinforcing Bars in Solution and Cathodic Debonding Tests: Phase II Screening Tests", Report No. FHWA-RD-96-021, Washington, D. C., 1996.

[14] H. J. Dagher, and S. Kulendran, "Finite Element Modeling of Corrosion Damage in Concrete". ACI Struc. Jour. , Vol. 89, No. 6, 1992, pp. 699708.

[15] S. E. Hussain, A. Rasheeduzzafar, A. Al-Mussallam, and A. S. AlGahtani, "Factors Affecting Threshold Chloride for Reinforcement Corrosion in Concrete". Cement \& Conc. Research, Vol.25, No.7, 1995, pp.1543-1555.

[16] K. Pettersson, "Chloride Threshold Value and the Corrosion Rate in Reinforced Concrete". Ceme.\& Conc. Res., Vol. 20, 1994, pp.461-470..

[17] Y. P. Virmani, "Corrosion Protection Systems for Construction and Rehabilitation of Salt-Contaminated Reinforced Concrete bridge members", Proceeding of the International Conference on Repair of Concrete Structures-From Theory to Practice in a Marine Environment, Svolvaer, Norway, 1997, pp. 107-122.

[18] A-Kh. M. Hussain, "The Laboratory Determination of Longitudinal and Lateral Dispersion Coefficients in Unidirectional Groundwater Flow". A Thesis submitted to the University of Newcastle upon Tyne for the Degree of Doctor of Philosophy, Department of Civil Engineering, University of Newcastle upon Tyne, England, U.K., 1981, Appendix A, PP.275. 